\title{
The Hajdu Cheney Mutation Is a Determinant of B-Cell Allocation of the Splenic Marginal Zone
}

\author{
Jungeun $\mathrm{Yu}{ }^{*}$ Stefano Zanotti, ${ }^{* \dagger}$ Bhavita Walia, ${ }^{\ddagger}$ Evan Jellison, ${ }^{\S}$ Archana Sanjay, ${ }^{*}$ and Ernesto Canalis ${ }^{* \dagger}$
}

From the Departments of Orthopaedic Surgery* and Medicine, ${ }^{\dagger}$ UConn Musculoskeletal Institute, and the Departments of Genetics and Developmental Biology $y^{\ddagger}$ and Immunology, ${ }^{\S}$ UConn Health, Farmington, Connecticut

\author{
Accepted for publication \\ September 21, 2017. \\ Address correspondence to \\ Ernesto Canalis, M.D., or \\ Archana Sanjay, Ph.D., \\ Department of Orthopaedic \\ Surgery, UConn Health, \\ Farmington, CT 06030- \\ 5456. E-mail: canalis@uchc. \\ edu or asanjay@uchc.edu.
}

\begin{abstract}
The neurogenic locus notch homolog protein (Notch)-2 receptor is a determinant of B-cell allocation, and gain-of-NOTCH2-function mutations are associated with Hajdu-Cheney syndrome (HCS), a disease presenting with osteoporosis and acro-osteolysis. We generated a mouse model reproducing the HCS mutation (Notch2HCS), and heterozygous global mutant mice displayed gain-of-Notch2 function. In the mutant spleen, the characteristic perifollicular rim marking the marginal zone (MZ), which is the interface between the nonlymphoid red pulp and the lymphoid white pulp, merged with components of the white pulp. As a consequence, the MZ of Notch2HCS mice occupied most of the splenic structure. To explore the mechanisms involved, lymphocyte populations from the bone marrow and spleen were harvested from heterozygous Notch2HCS mice and sex-matched control littermates and analyzed by flow cytometry. Notch2HCS mice had an increase in $\mathrm{CD} 21 / 35^{\text {high }} \mathrm{CD} 23^{-}$splenic MZ B cells of approximately fivefold and a proportional decrease in splenic follicular $B$ cells $\left(C D 21 / 35^{\text {int }} C D 23^{+}\right)$at 1,2 , and 12 months of age. Western blot analysis revealed that Notch2HCS mutant splenocytes had increased phospho-Akt and phospho-Jun N-terminal kinase, and gene expression analysis of splenic CD19 ${ }^{+} \mathrm{B}$ cells demonstrated induction of Hes1 and Hes5 in Notch2HCS mutants. Anti-Notch2 antibodies decreased MZ B cells in control and Notch2HCS mice. In conclusion, Notch2HCS mutant mice have increased mature B cells in the MZ of the spleen. (Am J Pathol 2018, 188: 149-159; https://doi.org/10.1016/j.ajpath.2017.09.010)
\end{abstract}

Newly generated transitional type $1 \mathrm{~B}$ cells actively leave the bone marrow to enter the peripheral circulation and reach lymphoid organs and the spleen, where they develop further into transitional type 2 and mature B cells. ${ }^{1,2}$ Follicular B cells are present in follicular structures of secondary lymphoid organs and are characterized by their ability to recirculate, whereas marginal zone (MZ) B cells reside in the spleen at the junction of the red and white pulp. ${ }^{3,4}$ Follicular B cells constitute the majority of peripheral $\mathrm{B}$ cells and differentiate into plasma cells or memory B cells in response to antigens. MZ B cells rapidly differentiate into plasma cells after interactions with bloodborne bacteria. ${ }^{1,5}$ Whereas the rodent MZ is well defined, with a cell population representing a distinct B-cell lineage that is restricted to the splenic MZ, the human MZ is not well defined, and B cells have a pregerminal center genotype and phenotype. ${ }^{6}$ Therefore, the human equivalent of the MZ is minor, precluding major extrapolations of findings from mice to humans.
Neurogenic locus notch homolog proteins (Notch) are four single-pass transmembrane receptors that influence cell fate decisions. The activation of Notch ensues after its interactions with cognate ligands of the protein jagged (Jagged) and $\delta$-like families, leading to the proteolytic cleavage of the receptor and the release of the Notch intracellular domain (NICD). ${ }^{7}$ The NICD translocates into the nucleus, where it forms a complex with recombination signal binding protein for Ig of the $\kappa$ region (Rbpjא) and mastermind-like protein to induce the transcription of target genes, such as those encoding transcription factor HES (HES) and hairy/enhancer-of-split related with YRPW motif protein (Hey). ${ }^{8-11}$ Notch1 is expressed preferentially in T cells, and its inactivation prevents T-cell development and causes

Supported by National Institute of Diabetes and Digestive and Kidney Diseases grant DK045227 (E.C.).

A.S. and E.C. contributed equally to this work as senior authors.

Disclosures: Genentech provided anti-Notch2 negative regulatory region and anti-ragweed antibodies. 
ectopic B-cell development in the thymus. ${ }^{12}$ Notch2 is expressed preferentially in maturing B cells, and Notch2 signaling is indispensable for MZ B-cell development. ${ }^{13,14}$ Notch2 haploinsufficiency, the conditional inactivation of Notch2 in Mx- or CD19-expressing cells, and the inactivation of Rbpjк in CD19-expressing cells, all result in a marked reduction in MZ B cells in the spleen. ${ }^{15-17}$ Accordingly, Notch2 overexpression in CD19-expressing cells leads to the allocation of $\mathrm{B}$ cells to the MZ of the spleen. ${ }^{18}$

Hajdu-Cheney syndrome (HCS) is a rare genetic disease characterized by craniofacial developmental abnormalities, acro-osteolysis, platybasia, severe osteoporosis, and occasional splenomegaly. ${ }^{19-22} \mathrm{HCS}$ is associated with point mutations or short deletions in exon 34 of $\mathrm{NOTCH} 2$, leading to the creation of a stop codon upstream of the proline, glutamic acid, serine, and threonine (PEST) domain but downstream of sequences required for transcriptional activity. ${ }^{23-27}$ Since the PEST domain is necessary for the ubiquitination and degradation of $\mathrm{NOTCH} 2$, the mutations result in the translation of a stable protein product and presumably gain-of-NOTCH2 function. Importantly, somatic mutations in the same region of exon 34 of $\mathrm{NOTCH} 2$ are associated with diffuse large B-cell lymphomas and lymphomas of the MZ of the spleen. ${ }^{28-30}$

To gain an understanding of the pathophysiology of HCS, we generated a mouse model, termed Notch $2 H C S$ mutant, harboring a Notch 2 mutation $(6955 \mathrm{C}>\mathrm{T})$ and leading to the generation of a stop codon in exon 34, upstream of the PEST domain, and the predicted translation of a truncated Notch2 protein of 2318 amino acids. ${ }^{31}$ Our aim was to address whether the Notch2HCS mutant mouse develops a B-cell phenotype and whether the phenotype can be reversed by pharmacologic intervention. To this end, Notch $2 \mathrm{HCS}$ mice were treated with a specific and well-characterized antibody directed to the negative regulatory region (NRR) of Notch2, the site of the initial cleavage of Notch required for signal activation. ${ }^{7,32-34}$ The bone marrow and spleen compartments in the Notch2HCS mutant mice were characterized by flow cytometry.

\section{Materials and Methods}

\section{Hajdu-Cheney Mutant Mice}

To generate a mouse model of HCS, a $6955 \mathrm{C}>\mathrm{T}$ substitution was introduced into the mouse Notch 2 locus by homologous recombination, as previously reported. ${ }^{31}$ After the removal of the neomycin selection cassette, the Notch 2 mutation was confirmed by sequencing of genomic DNA from F1 pups, and mice were backcrossed into a C57BL/6J background for at least eight generations. Genotyping of Notch2HCS mice was conducted in tail DNA extracts by PCR using forward primer Nch2Lox gtF $5^{\prime}$-CCCTTCTCTCTGTGCGGTAG-3' and reverse primer Nch2Lox gtR 5'-CTCAGAGCCAAAGCCTCACTG-3' (Integrated DNA Technologies, Coralville, IA). Heterozygous Notch2HCS mutant and sex-matched control littermates were studied and obtained by crossing heterozygous Notch $2 \mathrm{HCS}$ mice with wild-type mice.

\section{Administration of Anti-Notch2 Antibodies}

One-month-old male Notch $2 H C S$ mutant mice and sexmatched control littermates were administered anti-Notch2 NRR or anti-ragweed antibody (gifted from Genentech, South San Francisco, CA) in phosphate-buffered saline at a dose of $10 \mathrm{mg} / \mathrm{kg}$ intraperitoneally twice a week for 4 consecutive weeks and sacrificed at 2 months of age. ${ }^{35}$ The dose of the antibody was selected on the basis of available data showing effects of anti-Notch2 NRR antibody in vivo at doses between 2 and $30 \mathrm{mg} / \mathrm{kg}$, information on the lack of antibody-dependent gastrointestinal toxicity when used at a dose of $5 \mathrm{mg} / \mathrm{kg}$, and data on its predicted half-life based on the known half-life of IgGs. ${ }^{33,36-39}$ Study protocols were approved by the Institutional Animal Care and Use Committee at UConn Health (Farmington, CT).

\section{Histologic Examination and Immunofluorescence}

To prepare sections for histologic examination, organs were fixed in $10 \%$ neutral buffered formalin, dehydrated in ethanol and xylenes, and embedded in paraffin; sections were cut and stained with hematoxylin and eosin at Alizee Pathology (Baltimore, MD). To generate frozen sections for immunofluorescence, spleens were fixed in $1 \%$ paraformaldehyde overnight, exposed to $30 \%$ sucrose overnight, and embedded in optimal cutting temperature medium (Thermo Fisher Scientific, Waltham, MA). Seven-micron sections were cut, hydrated in phosphate-buffered saline, and treated with Alexa Fluor 647-conjugated anti-CD169 or phycoerythrinconjugated anti-IgM antibodies at a 1:100 dilution (BioLegend, San Diego, CA). Sections were counterstained with DAPI (Thermo Fisher Scientific) and mounted for fluorescent imaging. Sections were viewed on a fluorescence microscope (model DMI6000B; Leica Microsystems, Buffalo Grove, IL), and images were collected using the Leica Application Suite $\mathrm{X}$ software version 1.5.1.1387 (Leica Microsystems).

\section{Flow Cytometry}

To release splenocytes, spleens were disrupted by gentle pressing of the organ between two glass slides. Bone marrow cells were obtained by flushing femurs and tibias with a 26-gauge needle, after the removal of both epiphyseal ends. After the lysis of erythrocytes using buffer containing 150 $\mathrm{mmol} / \mathrm{L}$ ammonium chloride, $10 \mathrm{mmol} / \mathrm{L}$ potassium chloride, and $0.1 \mathrm{mmol} / \mathrm{L}$ EDTA (ammonium-chloride-potassium buffer), approximately $4 \times 10^{6}$ cells/mouse were collected in cell-staining medium containing 4-(2-hydroxyethyl)-1piperazineethanesulfonic acid (Sigma-Aldrich, St. Louis, MO) and $2 \%$ heat-inactivated fetal bovine serum (Gibco, Hampton, $\mathrm{NH}$ ) in Hanks' balanced salt solution. Flow cytometry was performed using a combination of antibodies (BioLegend; eBioscience, Santa Clara, CA) (Table 1) at a 1:400 dilution $(0.25 \mu \mathrm{g} / \mu \mathrm{L})$ in staining medium for 1 hour on ice. Cells were washed in cell-staining medium, stained for live-dead cells with 
Table 1 Antibodies Used for Flow Cytometry

\begin{tabular}{|c|c|c|}
\hline Antibody & Clone & Source \\
\hline Anti-CD45R Alexa Fluor 700 & RA3-6B2 & $\begin{array}{l}\text { eBioscience } \\
\quad(\text { Santa Clara, CA) }\end{array}$ \\
\hline Anti-CD19 FITC & MB19-1 & $\begin{array}{l}\text { BioLegend } \\
\quad \text { (San Diego, CA) }\end{array}$ \\
\hline Anti-CD117 Brilliant Violet 421 & 2B8 & BioLegend \\
\hline Anti-IgM PE & RMM-1 & BioLegend \\
\hline Anti-CD45 APC-Cy7 & 3D-F11 & BioLegend \\
\hline Anti-CD23 Brilliant Violet 510 & B3B4 & BioLegend \\
\hline Anti-CD21/CD35 PE-Cy7 & $7 G 9$ & BioLegend \\
\hline Anti-CD138 APC & $281-2$ & BioLegend \\
\hline Anti-CD3e PE/Dazzle 594 & $145-2 C 11$ & BioLegend \\
\hline
\end{tabular}

APC, allophycocyanin; FITC, fluorescein isothiocyanate; PE, phycoerythrin.

Zombie UV dye (BioLegend) at 1:200 dilution, and analyzed using a BD LSR II flow cytometer (BD Biosciences, San Jose, CA). After gating for live-dead cell staining and background staining using isotype controls, the absolute number and the percentage of different cell populations were analyzed using FlowJo software version 10.2 (Tree Star, Ashland, OR).

\section{Quantitative RT-PCR}

Total RNA was extracted from B cells purified from spleen suspensions enriched in $\mathrm{CD} 19^{+}$cells by magnetic positive selection using the autoMACS Pro Separator system (Miltenyi Biotec, San Diego, CA). The purity of isolated CD19 ${ }^{+}$cells was verified by flow cytometry, and mRNA levels were determined by quantitative RT-PCR. ${ }^{40,41}$ For this purpose, equal amounts of RNA were reverse-transcribed using the iScript RT-PCR kit (Bio-Rad Laboratories, Hercules, CA), according to the manufacturer's instructions, and amplified in the presence of specific primers (all primers from Integrated DNA Technologies) (Table 2) and iQ SYBR Green Supermix (Bio-Rad), at $60^{\circ} \mathrm{C}$ for 35 cycles. Transcript copy numbers were estimated by comparison to a serial dilution of cDNA for Hes1 (ATCC, Manassas, VA), Hes5 (gifted from Ryochiro Kageyama, Kyoto University, Kyoto, Japan), and ribosomal protein L38 (Rpl38; ATCC). ${ }^{42}$ To measure the levels of the Notch $2^{6955 \mathrm{C}>\mathrm{T}}$ mutant transcript, total RNA was reversetranscribed with Moloney Murine Leukemia Virus Reverse
Transcriptase (Life Technologies, Grand Island, NY) in accordance with the manufacturer's instructions, in the presence of reverse primers for Notch2 and for Rpl38 (Table 2). Notch 2 cDNA was amplified by PCR in the presence of specific primers (Table 2), a tetrachlorofluorescein-labeled DNA probe of sequence $5^{\prime}$-CATTGCCTAGGCAGC-3' covalently bound to a $3^{\prime}$-minor groove binder quencher (Life Technologies), and SsoAdvanced Universal Probes Supermix (Bio-Rad) at $60^{\circ} \mathrm{C}$ for 45 cycles. ${ }^{43}$ Notch $2^{6955 \mathrm{C}>\mathrm{T}}$ transcript copy number was estimated by comparison with a serial dilution of a synthetic DNA fragment (Integrated DNA Technologies) containing approximately $200 \mathrm{bp}$ surrounding the $6955 \mathrm{C}>\mathrm{T}$ mutation in the Notch2 locus, and cloned into pcDNA3.1(-) (Life Technologies) by isothermal single-reaction assembly using commercially available reagents (New England BioLabs, Ipswich, MA). ${ }^{44}$ Amplification reactions were conducted in a CFX96 quantitative RT-PCR detection system (Bio-Rad), and fluorescence was monitored during every PCR cycle at the annealing step. Data are expressed as copy number corrected for Rpl38 copy number.

\section{Western Blot Analysis}

Isolated spleen cells were treated with ammonium-chloridepotassium buffer to lyse erythrocytes, and the cell suspension was centrifuged. Cells were lysed in buffer containing $150 \mathrm{mmol} / \mathrm{L}$ sodium chloride, $25 \mathrm{mmol} / \mathrm{L}$ Tris-HCI $(\mathrm{pH}$ 7.5), $5 \%$ glycerol, $0.5 \%$ TritonX-100, $0.1 \%$ sodium deoxycholate, $0.1 \%$ sodium dodecyl sulfate, $1 \mathrm{mmol} / \mathrm{L}$ EDTA, $1 \mathrm{mmol} / \mathrm{L}$ sodium orthovanadate, $10 \mathrm{mmol} / \mathrm{L}$ sodium fluoride, and protease inhibitor cocktail (Sigma-Aldrich). Clarified total cell lysate was fractionated by SDS-PAGE on $4 \%$ to $15 \%$ gradient polyacrylamide gels, as previously described. ${ }^{45}$ Western blots were probed for Akt phosphorylation using a phospho-specific (anti-phospho-Akt Ser473) antibody or for Jun N-terminal kinase phosphorylation using an anti-phospho-Jun N-terminal kinase antibody (both from Cell Signaling Technology, Danvers, MA). To detect the Notch2 NICD, a hybridoma-produced monoclonal antibody against Notch2 (c651.6DbHN; Developmental Studies Hybridoma Bank, University of Iowa, Iowa City, IA), generated with an epitope coded by bp 6508 to

Table 2 Primers Used for RT-qPCR Determinations

\begin{tabular}{|c|c|c|c|}
\hline Gene & Strand & Sequence & GenBank accession number \\
\hline \multirow[t]{2}{*}{ Hes1 } & Forward & $5^{\prime}-\mathrm{ACCAAAGACGGCCTCTGAGCACAGAAAGT-3^{ \prime }}$ & NM_008235 \\
\hline & Reverse & $5^{\prime}$-ATTCTTGCCCTTCGCCTCTT-3' & \\
\hline \multirow[t]{2}{*}{ Hes5 } & Forward & $5^{\prime}$-GGAGATGCTCAGTCCCAAGGAG-3' & NM_010419 \\
\hline & Reverse & 5'-TGCTCTATGCTGCTGTTGATGC- $3^{\prime}$ & \\
\hline \multirow[t]{2}{*}{ Notch2 } & Forward & $5^{\prime}$-CATCGTGACTTTCCA-3' & NM_010928 \\
\hline & Reverse & $5^{\prime}$-GGATCTGGTACATAGAG-3' & \\
\hline
\end{tabular}

GenBank accession numbers (https://www.ncbi.nlm.nih.gov/genbank) identify the transcript recognized by primer pairs.

RT-qPCR, quantitative RT-PCR. 

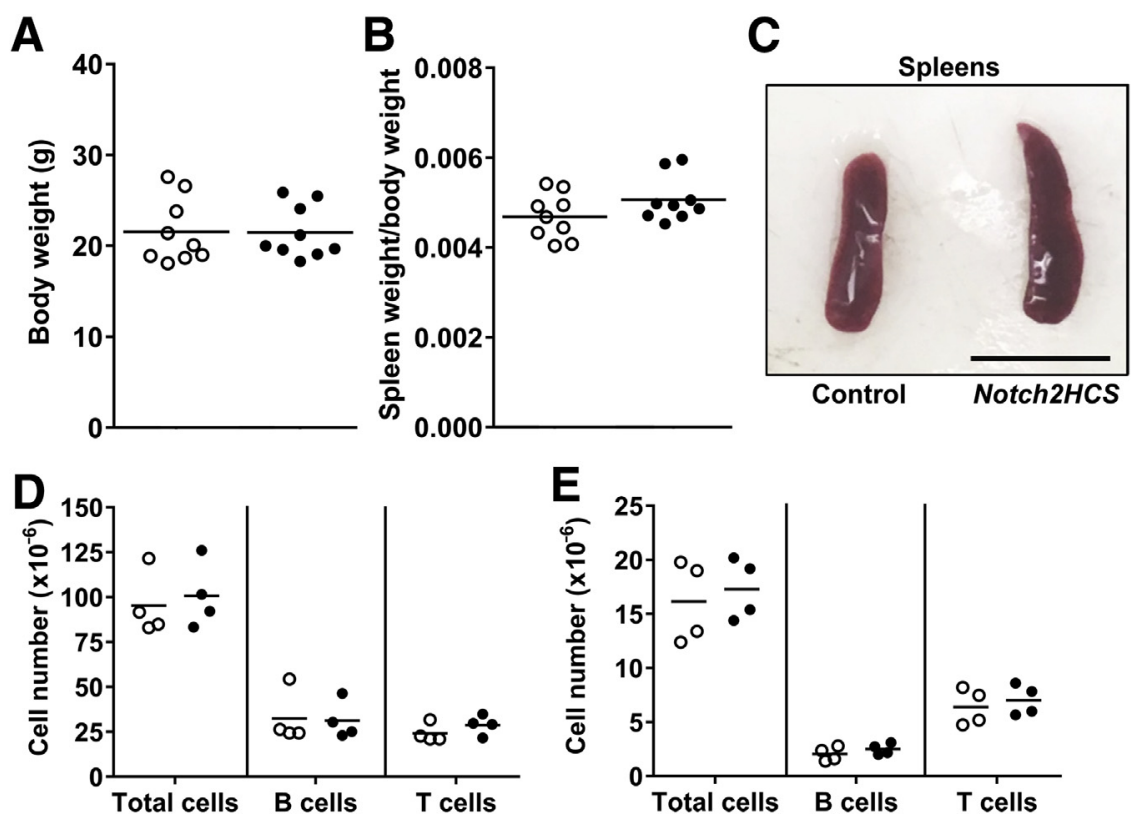

Figure 1 Weight, spleen weight, and lymphocyte number in control mice (open circles) and Notch2HCS mice (closed circles). A and B: Body weight $(\mathbf{A})$ and ratio of spleen weight/body weight (B) of 2-month-old control and Notch2HCS mutant male mice. C: Representative image of freshly isolated spleens from 2-month-old male control and Notch2HCS mice. D and E: Total numbers of cells, $\mathrm{B}_{2} 2 \mathrm{O}^{+} \mathrm{B}$ cells, and $\mathrm{CD}^{+} \mathrm{T}$ cells in the spleen (D) and bone marrow (E) in control and Notch2HCS mutant mice. Circles represent data from individual mice; horizontal bars represent mean values from biological replicates. Scale bar $=$ $1 \mathrm{~cm}$.
6906 of Notch2, was used. ${ }^{46}$ Blots were stripped and reprobed with anti-Akt, anti-Jun N-terminal kinase, or anti- $\beta$-actin antibodies (Cell Signaling) to verify uniformity of sample loading, as previously described. ${ }^{47}$ The amount of protein in individual bands was quantified using Odyssey Infrared Imaging Systems software version 2.1 (LI-COR Biosciences, Lincoln, NE), as previously reported. ${ }^{47,48}$

\section{Statistics}

Data are expressed as means $(95 \%$ CI). Statistical differences were determined by unpaired $t$-test or analysis of variance with Tukey post-hoc analysis for multiple comparisons.

\section{Results}

Hajdu-Cheney Mutant Mice Have Increased Numbers of Mature B Cells in the Spleen

In previous work, we described the generation of Notch2HCS mutant mice and the characterization of their skeletal phenotype. ${ }^{31}$ In the present studies, we determined the immunologic phenotype of the Notch $2 H C S$ mice. For this purpose, heterozygous Notch $2 H C S$ mutant mice were compared to wild-type mice because homozygosity of the Notch $2 H C S$ mutation results in perinatal lethality, and heterozygous mice have clear phenotypic manifestations. ${ }^{31}$

Table 3 B-Cell Populations in the Bone Marrow and Spleen of 2-Month-Old Notch2HCS Mutant Mice and Sex-Matched Littermate Controls

\begin{tabular}{|c|c|c|c|c|c|c|}
\hline \multirow{2}{*}{$\begin{array}{l}\text { Gate used } \\
\text { Cell population }\end{array}$} & \multicolumn{3}{|l|}{${\mathrm{B} 220^{+} \mathrm{IgM}^{-}}^{-}$} & \multicolumn{2}{|l|}{$\mathrm{B}^{2} 20^{+} \mathrm{CD} 19^{+} \mathrm{CD} 117^{-}$} & \multirow{2}{*}{$\begin{array}{l}\mathrm{B} 220^{-} \mathrm{CD}^{-} 9^{-} \\
{\mathrm{CD} 138^{+}}^{\text {plasma }}\end{array}$} \\
\hline & $\begin{array}{l}\mathrm{CD}_{19}{ }^{-} \mathrm{CD} 117^{-} \\
\text {Pre-pro-B }\end{array}$ & $\begin{array}{l}\mathrm{CD}_{19}{ }^{+} \mathrm{CD} 117^{+} \\
\text {Pro-B }\end{array}$ & $\begin{array}{l}\mathrm{CD}^{+} 9^{+} \mathrm{CD}_{117^{-}} \\
\text {Pre-B }\end{array}$ & $\mathrm{IgM}^{+}$ & $\operatorname{Ig} M^{\text {high }}$ & \\
\hline \multicolumn{7}{|l|}{ Bone Marrow } \\
\hline \multicolumn{7}{|l|}{ Male } \\
\hline Control & $28.1(22.3-33.9)$ & $1.2(0.8-1.7)$ & $70.1(64.3-75.9)$ & $43.7(39.1-48.3)$ & $19.8(13.9-25.7)$ & $1.1(1.0-1.2)$ \\
\hline Notch2HCS & $27.6(23.9-31.2)$ & $1.9(16-2.3)$ & $69.9(65-73.3)$ & $39.7(35.3-44.1)$ & $17.8(15.6-19.9)$ & $1.3(1.0-1.6)$ \\
\hline \multicolumn{7}{|l|}{ Female } \\
\hline Control & $44.3(37.2-51.4)$ & $7.4(6.6-8.3)$ & $39.1(32.3-45.9)$ & $55.6(53.1-58.0)$ & $11.4(10.2-12.6)$ & $2.4(1.5-3.4)$ \\
\hline Notch2HCS & $42.7(37.3-48.1)$ & $7.0(6.0-8.1)$ & $39.9(32.6-47.1)$ & $55.1(52.2-58.0)$ & $12.1(19.3-14.9)$ & $2.0(1.2-2.8)$ \\
\hline \multicolumn{7}{|l|}{ Spleen } \\
\hline Male & NA & NA & NA & & & \\
\hline Control & & & & $56.1(46.9-65.4)$ & $20.5(10.9-30.0)$ & $0.8(0.3-1.3)$ \\
\hline Notch2HCS & & & & $51.0(49.1-52.9)$ & $30.7(28.6-32.9)^{*}$ & $0.7(0.6-0.9)$ \\
\hline \multicolumn{7}{|l|}{ Female } \\
\hline Control & & & & $64.6(56.7-72.5)$ & $7.0(2.4-11.6)$ & $0.4(0.3-0.5)$ \\
\hline Notch2HCS & & & & $60.7(56.2-65.3)$ & $23.2(11.8-34.6)^{*}$ & $0.4(0.3-0.5)$ \\
\hline
\end{tabular}

Data are expressed as mean $(95 \% \mathrm{CI})$ percentages within the indicated gates of 4 biological replicates.

$* P<0.05$ Notch2HCS versus control.

$\mathrm{NA}$, not applicable. 
A

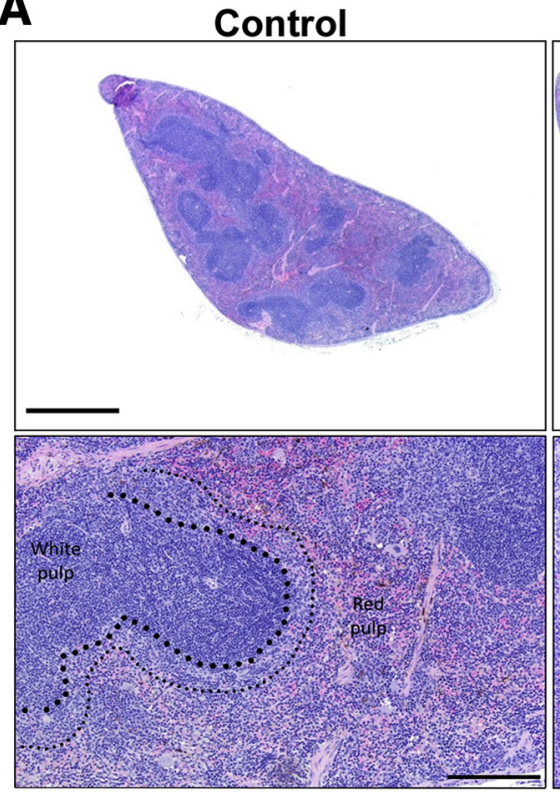

B
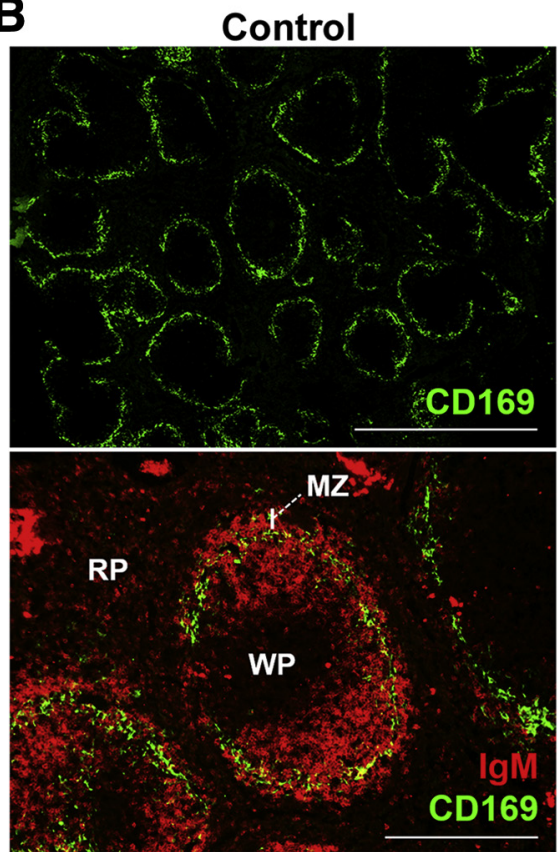

Notch2HCS

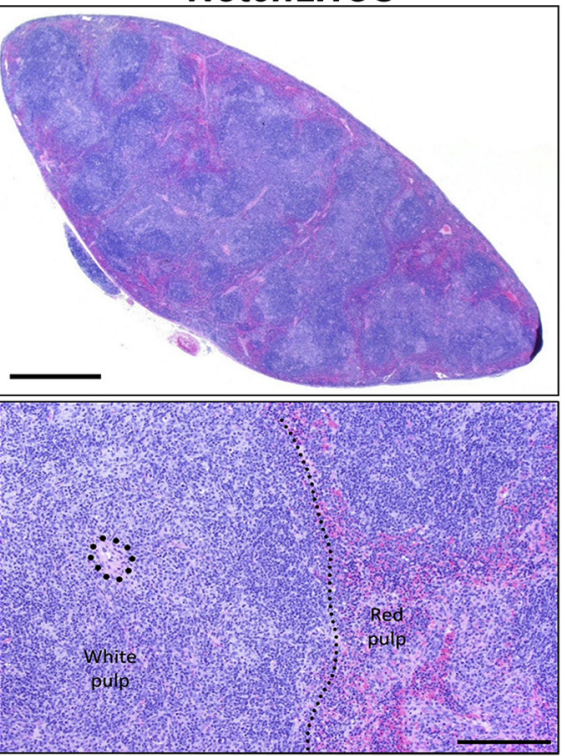

Notch2HCS

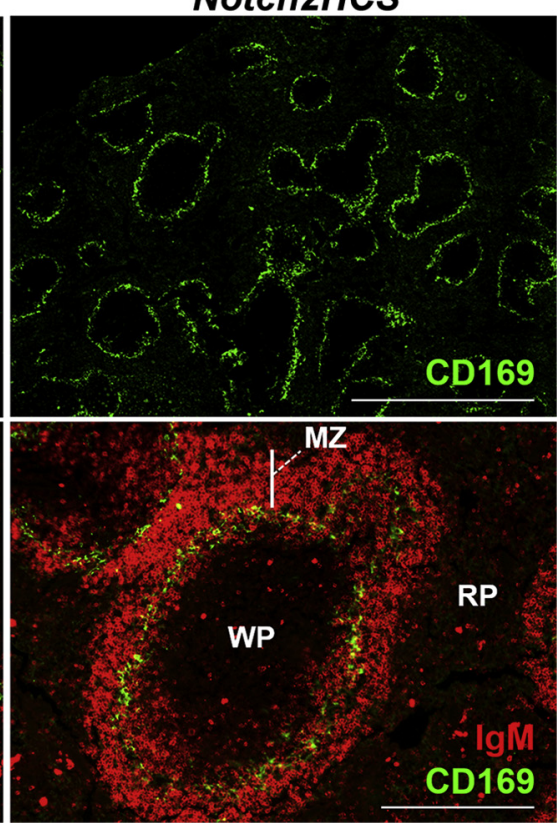

Figure 2 Architecture of the spleen in control and Notch2HCS mice. A: Representative paraffin sections derived from 6-month-old male mice stained with hematoxylin and eosin. Bottom panels show magnification of sections demonstrating enlargement of the white pulp (WP), the marginal zone (MZ), and the red pulp (RP) in Notch2HCS mutant and control mice. Large and small dots define the boundaries of the white and red pulp, respectively. B: Splenic architecture of control and Notch2HCS mice. Tile scans (top) of frozen sections stained with anti-CD169 Alexa Fluor 647 antibodies showing a characteristic perifollicular ring formed by $\mathrm{CD} 169^{+} \mathrm{MZ}$ macrophages. Bottom panels show images of representative follicles surrounded by macrophage and mature B-cell ring stained with anti-CD169 and anti-IgM-phycoerythrin antibodies. Vertical bars indicate the thickness of the MZ. The presence of nucleated cells was verified by DAPI staining (not shown). Scale bars: $1 \mathrm{~mm}$ (A and $\mathbf{B}$, top panels); $200 \mu \mathrm{m}$ (A, bottom panels); $250 \mu \mathrm{m}$ (B, bottom panels).
Heterozygous Notch2HCS mutant mice were obtained after heterozygous crossings with wild-type mice, all in a C57BL/6J genetic background, and compared to sexmatched control littermates. At 2 months of age, the weight of male or female Notch $2 H C S$ heterozygous mice was comparable to that of control littermates, and spleen weight/body weight was not different between mutant and control mice (Figure 1, A and B). Gross examination of the spleen revealed occasional mild splenomegaly in Notch2HCS mutant mice (Figure 1C), and flow cytometry demonstrated similar numbers of $\mathrm{B}_{2} 20^{+} \mathrm{B}$ cells and $\mathrm{CD} 3^{+}$ $\mathrm{T}$ cells in the spleen and bone marrow of mutant mice and wild-type controls (Figure 1, D and E). No change was observed in the number of $\mathrm{CD}^{+} \mathrm{T}$ cells in the thymus of mutant mice (data not shown).

Flow cytometry of $\mathrm{B}$ cells isolated from the bone marrow demonstrated that the frequencies of pre-pro $B$ cells $\left(\mathrm{B} 220^{+} \mathrm{CD}_{19} \mathrm{CD}^{-} 17^{-} \mathrm{IgM}^{-}\right)$, pro B cells $\left(\mathrm{B} 220^{+} \mathrm{CD} 19^{+}\right.$ $\left.\mathrm{CD}_{117^{+}} \mathrm{IgM}^{-}\right)$, pre B cells $\left(\mathrm{B} 220^{+} \mathrm{CD} 19^{+} \mathrm{CD}_{117^{-}} \mathrm{IgM}^{-}\right)$, $\mathrm{IgM}^{+} \mathrm{B}$ cells, and $\mathrm{IgM}^{\text {high }} \mathrm{B}$ cells were not different between Notch 2 HCS and control mice of either sex (Table 3). There were 1.5- and 3.3-fold increases in $\mathrm{IgM}^{\text {high }}$ mature B cells, respectively, in the spleens of male and female Notch $2 H C S$ mice compared with control mice of the same sex. This increase in mature $\operatorname{IgM}^{\text {high }}$ cells, however, did not result in an increased number of plasma cells (B220 ${ }^{-} \mathrm{CD}^{-} 9^{-} \mathrm{CD} 138^{+}$) (Table 3). 


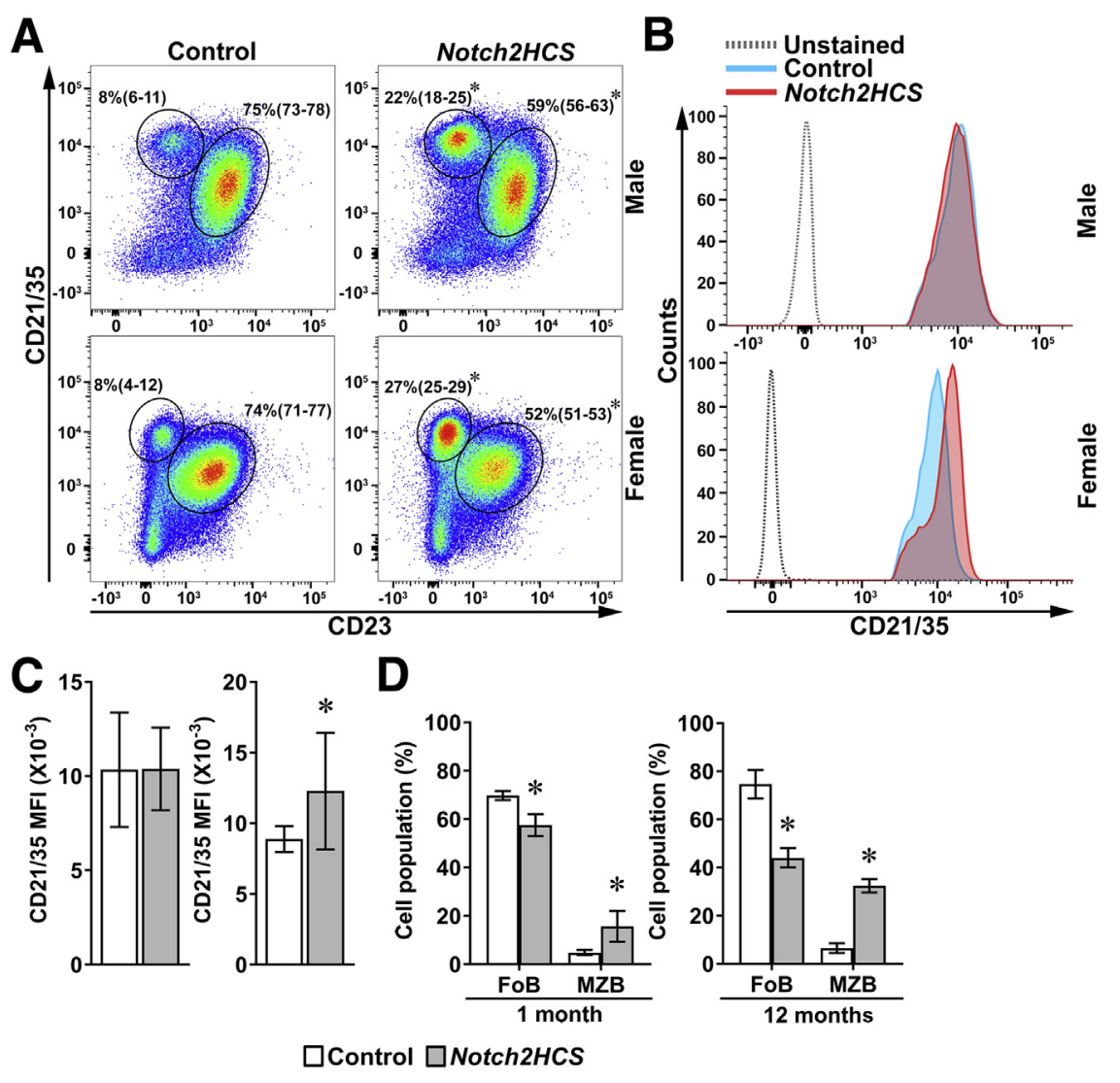

Figure 3 Flow cytometry of spleen cells from control and Notch2HCS mice. A: Representative dot plot of flow cytometry of spleen cells from 2-month-old male and female Notch2HCS and sexmatched control littermates. Cells were stained with anti-CD21/35 and anti-CD23 antibodies. Circled areas define $\mathrm{CD} 21 / 35^{\text {high }} \mathrm{CD} 23^{-}$marginal zone $B$ cells (MZBs) and $\mathrm{CD} 21 / 35^{\text {int }} \mathrm{CD} 23^{+}$follicular $B$ cells (FoBs) gated on $\mathrm{B}^{2} 20^{+} / \mathrm{CD} 19^{+} \mathrm{IgM}^{+} \mathrm{B}$-cell populations. B: Histogram of mean fluorescence intensity (MFI) of the CD21/35 cell population from 2-month-old male and female Notch2HCS and control mice. C: Bar graph of MFI of the CD21/ 35 cells for male and female 2-month-old control and Notch2HCS mice. D: Frequency of MZBs and FoBs from 1- and 12-month-old Notch2HCS mutant and wild-type control mice. Values are expressed as mean (95\% CI) frequencies of MZBs and $\mathrm{FoBs}(\mathbf{A})$; data are presented as means and $95 \%$ CI (C and D). $n=4$ biological replicates of control and experimental mice (C and D). ${ }^{\star} P<0.05$ versus control.

These findings suggest that the greater number of mature $\mathrm{B}$ cells in the spleen from Notch2HCS mutants is not due to a failure in the terminal differentiation of mature $\mathrm{B}$ cells.

\section{Splenic Architecture Is Not Affected in Hajdu-Cheney Mice}

Upon emigration from the bone marrow, newly formed B cells reach the spleen and progress through transitional stages in which the fates of MZ and follicular B cells are determined. ${ }^{1,3}$ Follicular B cells and MZ B-cell subsets reside in distinct anatomic locations, and the MZ separates the white and red pulp of the spleen. Analysis of histologic sections demonstrated that the white pulp occupied the majority of the spleen in three of four 6-month-old Notch2HCS mice and was constituted by MZ-like elements (Figure 2A). The increase in white pulp cellularity in Notch2HCS mutant mice may be related to alterations in splenic architecture. To address this possibility, CD169-expressing macrophages were identified in the spleen by immunofluorescence. This analysis did not reveal any overt abnormalities or disruption of the splenic architecture as the follicles were intact and the MZ macrophages formed the characteristic perifollicular rim (Figure 2B). Immunofluorescence of the same sections using anti-IgM antibodies demonstrated a greater number of mature $\operatorname{IgM}^{+} \mathrm{B}$ cells in the MZ of spleen sections derived from Notch $2 H C S$ mutant mice than in those from control littermates.
Hajdu-Cheney Mutant Mice Have Increased Marginal Zone B Cells in the Spleen

To assess the impact of the Notch2HCS mutation on the distribution of MZ and follicular B cells, flow cytometry of spleen cells from 2-month-old male and female Notch2HCS and sexmatched control littermate mice was conducted. This analysis demonstrated increases in the percentages of MZ B cells identified as $\mathrm{B} 220^{+} \mathrm{CD} 19^{+} \mathrm{CD} 21 / 35^{\text {high }} \mathrm{CD} 23^{-}$cells of approximately 3-fold (males) and 3.4-fold (females) in Notch2HCS mice compared with sex-matched control mice (Figure 3A). In association with these increases in MZ B-cell subset, the percentage of follicular B cells $\left(\mathrm{B} 220^{+} \mathrm{CD} 19^{+} \mathrm{CD} 21 / 35^{\text {int }} \mathrm{CD} 23^{+}\right)$ was decreased $20 \%$ to $30 \%$ in Notch $2 H C S$ compared with control mice. In agreement with the effect of Notch signaling on the induction of $\mathrm{CD} 21^{+}$but not $\mathrm{CD} 23^{+}$cells, the mean fluorescence intensity, representing the surface expression of $\mathrm{CD} 21$, was increased in the B cells of female Notch2HCS mice compared with sex-matched controls (Figure 3, B and C). CD21 mean fluorescence intensity was comparable between male Notch2HCS mice and male control littermates.

To understand the impact of the Notch2HCS mutation on the development of the MZ B cells and to determine the sustainability of the effect observed, flow cytometry also was performed in 1-month-old mice, early in the development of mature splenic B-cell subsets, and in 12-month-old mice. The percentage of MZ B cells was significantly increased and the 


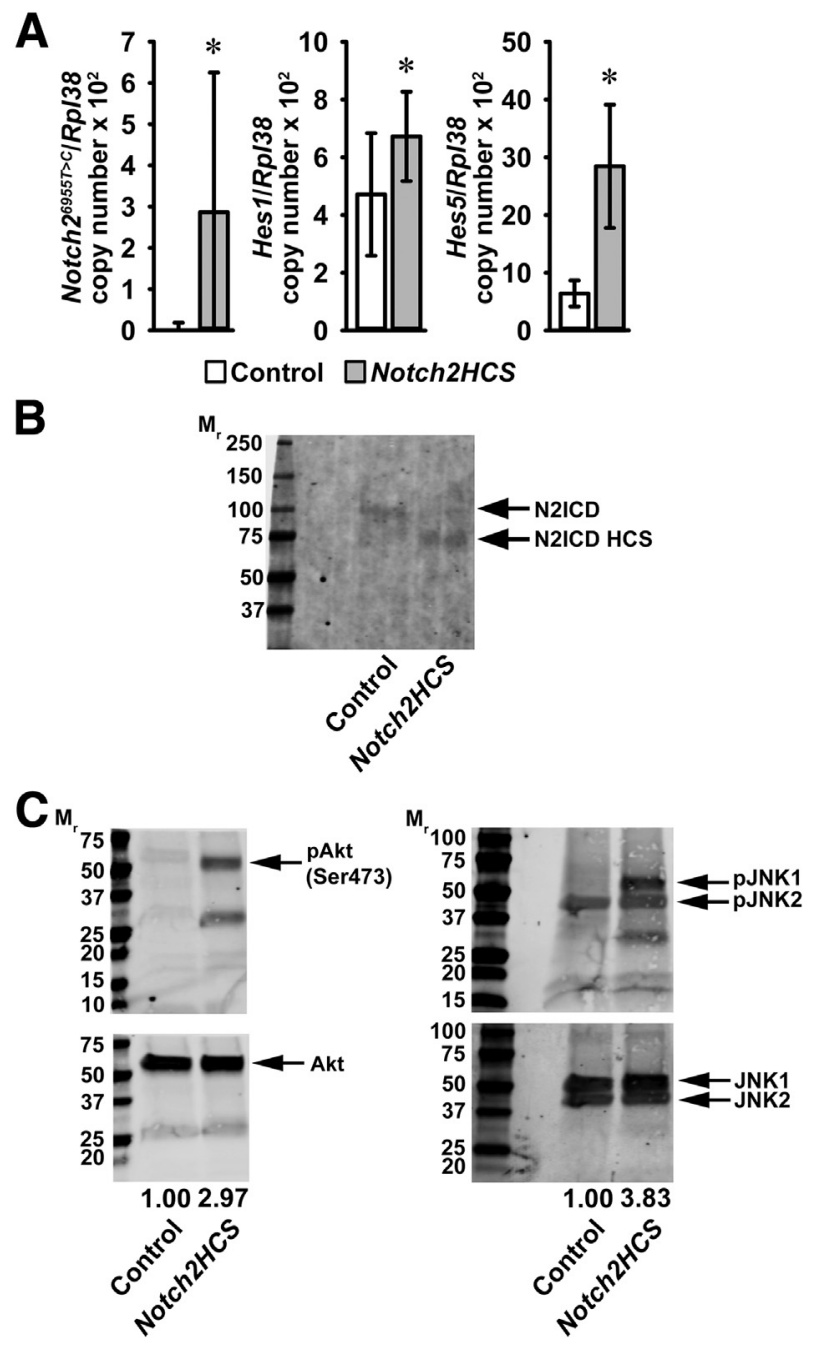

Figure 4 Expression of Notch2 target genes and mitogen-activated protein kinase and phosphatidylinositol 3 kinase (PI3K)/Akt signaling pathway elements in Notch2HCS and littermate control mice. A: Total RNA from CD19 ${ }^{+}$ cells was extracted and gene expression determined by quantitative RT-PCR. B and C: Western blot analysis of total cell lysates $(100 \mu \mathrm{g})$ from spleen cells was fractionated by SDS-PAGE, and blots were probed in B with anti-Notch2 antibodies to detect the Notch2 intracellular domain (N2ICD) and in C with anti-phospho-Akt (pAkt) Ser473 and anti-phospho-Jun N-terminal kinase (pJNK) antibodies. Blots were stripped and reprobed with anti-Akt, anti-JNK, or anti- $\beta$-actin antibodies to verify protein loading. The ratios of pAkt/Akt to pJNK/JNK were quantified by Odyssey Infrared Imaging Systems software version 2.1 (LI-COR Biosciences, Lincoln, NE) and are shown under each blot. Molecular weight $\left(\mathrm{M}_{\mathrm{r}}\right)$ ladder is shown along the left. Data are expressed as mean $(95 \%$ CI $)$ copy numbers of Notch $2^{6955 T>C}$ mutant, Hes5, and Hes1, corrected for $R p l 38$ (A). $n=4$ biological replicates (A). ${ }^{*} P<0.05$ between Notch2HCS mutant and wild-type control cells (A).

percentage of follicular B cells was decreased in 1- and 12-month-old Notch2HCS mutant mice compared with those in sex-matched controls (Figure 3D).

\section{Mechanisms Operational in Hajdu-Cheney Mutant Mice}

To explore the mechanisms that may explain the B-cell phenotype of Notch2HCS mutant mice, RNA was extracted from $\mathrm{CD} 19^{+} \mathrm{B}$ cells from the spleens of mutant and control mice. Quantitative RT-PCR demonstrated the expression of Notch $2^{6955 \mathrm{C}>\mathrm{T}}$ transcripts and increased mRNA levels of the Notch target genes Hesl and Hes 5 in $\mathrm{CD}_{1} 9^{+} \mathrm{B}$ cells from Notch $2 \mathrm{HCS}$ mutant mice, confirming activation of Notch signaling in spleen cells (Figure 4A). In accordance with the predicted truncation of the NICD, Western blot analysis of spleen cells demonstrated the expression of a truncated Notch2 NICD migrates with a molecular mass of $75 \mathrm{kDa}$ in Notch2HCS cells, and an intact Notch2 NICD, with a molecular mass of $110 \mathrm{kDa}$, in cells from wild-type mice (Figure 4B). Notch2 activation affected the mitogenactivated protein and the phosphatidylinositol 3 kinaseAkt signaling pathways. Western blot analysis of spleen lysates revealed marked increases in Akt and Jun N-terminal kinase phosphorylation in lysates derived from Notch $2 H C S$ mutants compared with those in controls (Figure 4C).

\section{Anti-Notch2 NRR Antibodies Decrease MZ B Cells in Wild-Type and Hajdu-Cheney Mutant Mice}

To determine whether the B-cell splenic phenotype of the Notch $2 \mathrm{HCS}$ mouse model can be prevented by pharmacologic intervention, male Notch $2 \mathrm{HCS}$ mice were treated with a specific and well-characterized antibody directed to the NRR of Notch2. ${ }^{33}$ The administration of anti-Notch2 NRR antibodies did not result in any apparent unwanted effects or obvious gastrointestinal toxicity; the mice appeared healthy, and their weight was not decreased. ${ }^{35}$ The B-cell populations in the bone marrow were not affected by anti-Notch2 NRR antibodies (Table 4). Flow cytometry of the spleen B-cell population demonstrated that anti-Notch2 NRR antibodies decreased the IgM ${ }^{\text {high }}$ mature B-cell population in wild-type and Notch2HCS mice without altering the frequency of plasma cells (Table 4). Treatment of Notch2HCS mice with anti-Notch2 NRR antibodies prevented the effect of the mutation on follicular and MZ B-cell allocation in the spleen. Moreover, anti-Notch2 NRR antibodies decreased the frequency of MZ B cells in wild-type and Notch2HCS mice to virtually undetectable levels (Figure 5). Anti-Notch2 NRR antibodies did not alter the frequency of follicular B cells in control mice, but reversed the decrease caused by the Notch2HCS mutation (Figure 5).

\section{Discussion}

The present study demonstrates that a Notch2 gain-of-function mutation, replicating the one found in HCS, increases the mature B-cell population in the MZ. We demonstrate that irrespective of sex or age, Notch2HCS mice have an increase in MZ B cells and a reduction in follicular B cells in the spleen. The decrease in follicular B cells was proportional to the increase in MZ B cells, suggesting that upon Notch2 activation a shift in the differentiation of precursor cells toward MZ B cells ensued. This possibility is in accordance with recent work demonstrating a 
Table 4 B-Cell Populations in the Bone Marrow and Spleen of 2-Month-Old Notch2HCS Mutant Male Mice and Sex-Matched Littermate Controls Treated with Anti-Notch2 NRR or Anti-Ragweed Control Antibody, Both at $10 \mathrm{mg} / \mathrm{kg}$, for 4 Weeks

\begin{tabular}{|c|c|c|c|c|c|c|}
\hline \multirow{2}{*}{$\begin{array}{l}\text { Gate used } \\
\text { Cell population }\end{array}$} & \multicolumn{3}{|l|}{$\mathrm{B}^{2} 20^{+} \mathrm{IgM}^{-}$} & \multicolumn{2}{|c|}{$\mathrm{B}^{2} 20^{+} \mathrm{CD} 19^{+} \mathrm{CD} 117^{-}$} & \multirow{2}{*}{$\begin{array}{l}{\mathrm{B} 220^{-} \mathrm{CD}^{-} 9^{-}}^{\mathrm{CD} 138^{+} \text {plasm }} \\
\end{array}$} \\
\hline & $\begin{array}{l}\mathrm{CD}_{19}{ }^{-} \mathrm{CD} 117^{-} \\
\text {Pre-pro-B }\end{array}$ & $\begin{array}{l}\mathrm{CD}_{19}{ }^{+} \mathrm{CD} 117^{+} \\
\text {Pro-B }\end{array}$ & $\begin{array}{l}\text { CD19 }{ }^{+} \mathrm{CD}_{117^{-}} \\
\text {Pre-B }\end{array}$ & $\mathrm{IgM}^{+}$ & $\operatorname{Ig}^{\text {high }}$ & \\
\hline \multicolumn{7}{|l|}{ Bone marrow } \\
\hline \multicolumn{7}{|l|}{ Control } \\
\hline Control & $48.1(33.8-62.4)$ & $3.5(1.2-5.7)$ & $39.3(23.8-54.8)$ & $45.2(38.3-52.1)$ & $29.2(25.3-33.2)$ & $5.2(4.0-6.5)$ \\
\hline Notch2HCS & $54.4(51.6-57.3)$ & $2.7(2.2-3.1)$ & $34.5(28.7-40.2)$ & $55.7(46.8-64.5)$ & $21.8(9.4-34.2)$ & $4.5(3.4-5.6)$ \\
\hline \multicolumn{7}{|c|}{ Anti-Notch2 NRR } \\
\hline Control & $53.9(41.3-66.4)$ & $2.5(1.8-3.2)$ & $35.2(25.5-45.1)$ & $48.6(34.5-62.8)$ & $22.8(7.5-38.1)$ & $6.3(5.4-7.2)$ \\
\hline Notch2HCS & $56.6(44.2-69.1)$ & $2.2(0.7-3.7)$ & $33.0(16.7-49.7)$ & $49.7(42.0-57.4)$ & $21.6(10.1-33.1)$ & $5.1(3.1-6.8)$ \\
\hline \multicolumn{7}{|l|}{ Spleen } \\
\hline Control & NA & NA & NA & & & \\
\hline Control & & & & $52.4(50.7-54.1)$ & $16.6(14.0-19.2)$ & $0.9(0.7-1.1)$ \\
\hline Notch2HCS & & & & $52.8(48.8-56.3)$ & $31.2(23.1-39.3)^{*}$ & $0.9(0.2-1.6)$ \\
\hline \multicolumn{7}{|c|}{ Anti-Notch2 NRR } \\
\hline Control & & & & $49.3(42.3-56.3)$ & $9.9(7.1-12.7)^{\dagger}$ & $0.8(0.5-1.0)$ \\
\hline Notch2HCS & & & & $50.1(46.7-53.4)$ & $9.6(5.9-13.4)^{\ddagger}$ & $0.9(0.7-1.1)$ \\
\hline
\end{tabular}

Data are expressed as mean (95\% CI) percentages within the indicated gates of four biological replicates.

$* P<0.05$ Notch $2 H C S$ versus control.

${ }^{\dagger} P<0.05$ anti-ragweed antibody-treated versus anti-Notch2 NRR antibody-treated wild-type mice.

${ }^{\ddagger} P<0.05$ anti-ragweed-treated versus anti-Notch2 NRR antibody-treated Notch2HCS mice.

$\mathrm{NA}$, not applicable; NRR, negative regulatory region.

correlation between disintegrin and metalloproteinase domain-containing protein (ADAM)-10 expression on type 1 B transitional cells and the final proportion size of MZ B cells. ${ }^{49}$ ADAM10 expression results in the activation of Notch signaling and the commitment of type $1 \mathrm{~B}$ transitional cells to $\mathrm{MZ} \mathrm{B}$ cells. ${ }^{49}$ Moreover, the conditional deletion of Adam10 in CD19expressing cells suppresses Notch2 signaling and alters type $1 \mathrm{~B}$ transitional cell differentiation so that the MZ does not develop and the number of follicular B cells increases. ${ }^{50}$ In agreement with previous work demonstrating that Notch signaling is dispensable for the development of early B cells, only mature B cells of the spleen were affected by the Notch 2 HCS mutation. ${ }^{15}$ Treatment of wild-type and Notch $2 H C S$ mutant mice with antiNotch2 NRR antibodies prevented the allocation of B cells to the $\mathrm{MZ}$ of the spleen.

Previous work has shown that Notch2 is preferentially expressed in mature B cells, and that Notch 2 haploinsufficiency, as well as the selective inactivation of Notch2 in Mx- and CD19expressing cells, result in a severe reduction in $\mathrm{MZ}$ mature $\mathrm{B}$ cells. ${ }^{15,16}$ Our studies are in agreement with work in which the overexpression of the Notch2 NICD in CD19 cells drove B cells toward the MZ B-cell compartment at the expense of follicular B cells. ${ }^{18}$ This finding would indicate that the effect of the Notch2 activation occurs in cells already committed to the B-cell lineage. The MZ B-cell phenotype of Notch $2 H C S$ mutants was observed at 1 month of age and was sustained through 1 year of age. This finding is congruent with the fact that the proper development of the MZ B-cell compartment in rodents occurs 3 to 4 weeks after birth. ${ }^{4,51}$

The mechanisms responsible for the effect of Notch2 activation on B-cell allocation in the spleen have not been elucidated, but may involve the induction of the Notch target genes Hesl and -5, as demonstrated in the present work. This mechanism is possible since these target genes depend on Notch canonical signal activation, and inactivation of Rbpj $\kappa$ in CD19expressing cells results in a loss of MZ B cells, with a concomitant increase in follicular B cells, a phenotype that is opposite to the one observed in mice with a gain-of-Notch2 function. ${ }^{14}$ However, a concomitant activation of noncanonical, non-Rbpjк-dependent Notch signaling is possible since the expression of E3 ubiquitin-protein ligase DTX1 in MZ B cells is prominent and is dependent on the expression of Notch2. ${ }^{15}$ In the present studies, we demonstrate the activation of Jun N-terminal kinase and phosphatidylinositol 3 kinase/Akt signaling in the spleen and confirm results obtained in a model of Notch2 overexpression in B cells. ${ }^{18}$ The activation of these signaling pathways may contribute to the B-cell phenotype and may or may not be a direct consequence of enhanced Notch signaling. For example, proline-rich tyrosine kinase 2, a tyrosine kinase linked to integrin signaling and to phosphatidylinositol 3 kinase activation, is downstream of Notch2 in cells of the myeloid lineage. ${ }^{52}$ Proline-rich tyrosine kinase 2 contributes to MZ B-cell migration and survival, and inactivation of prolinerich tyrosine kinase 2 results in the absence of the $\mathrm{MZ} .^{53}$ In addition, phosphatidylinositol 3 kinase can act downstream the $\mathrm{B}$-cell receptor and integrins, and regulate the migration and retention of MZ B cells. ${ }^{3,54}$

Although the constitutive activation of Notch1 or -2 is associated with an oncogenic effect in T and B cells, respectively, Notch2HCS mice did not exhibit obvious signs of malignancy or B-cell or splenic MZ lymphoma up to 1 year of age (E. Canalis, unpublished observations). The absence of lymphomas is in 

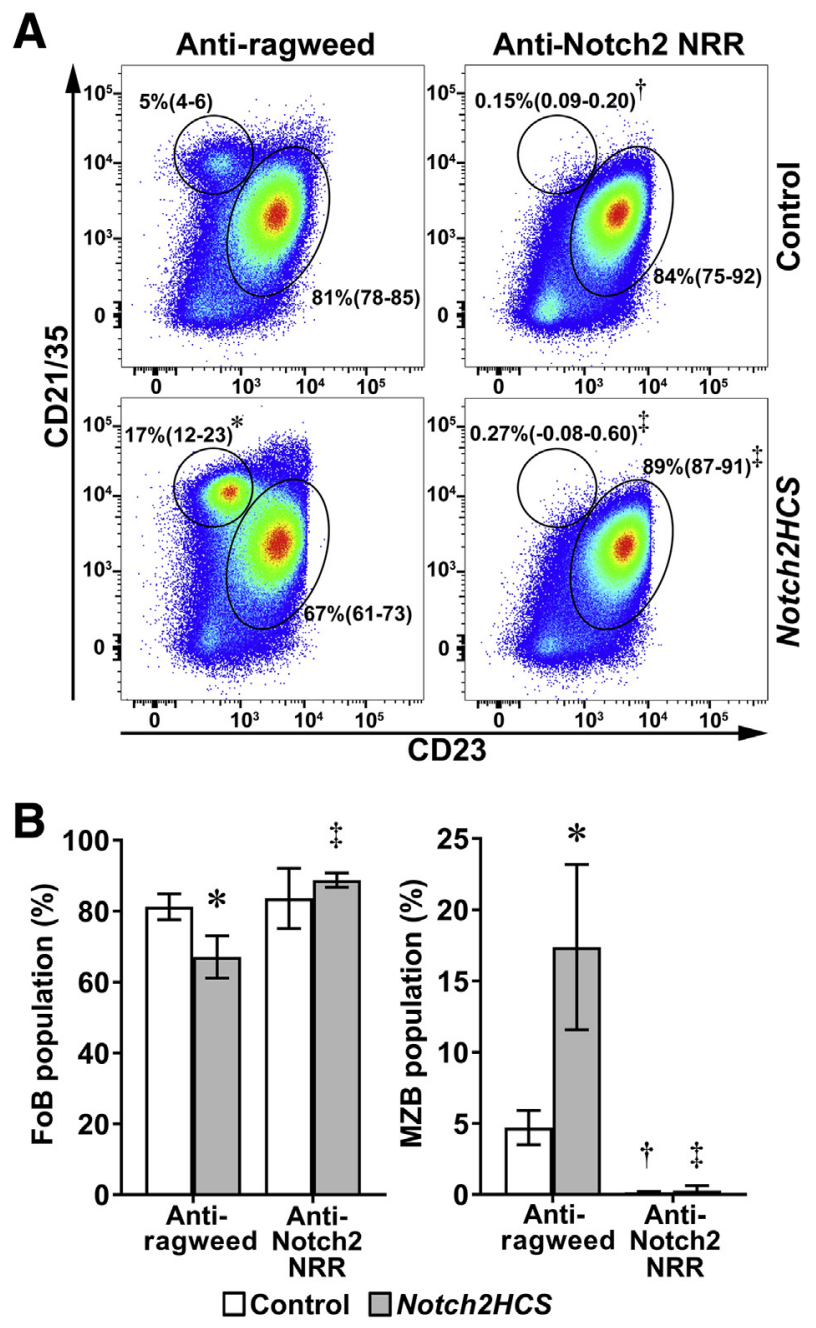

Figure 5 Distribution of marginal zone B cells (MZBs) assessed by flow cytometry of spleen cells isolated from 2-month-old Notch2HCS mutant male mice and sex-matched littermate controls treated with anti-Notch2 negative regulatory region (NRR) antibody or anti-ragweed control antibody, both at $10 \mathrm{mg} / \mathrm{kg}$ for 4 weeks before sacrifice. A: Representative dot plots of spleen cells from 2-month-old control mice and Notch2HCS mice treated with anti-ragweed antibodies or anti-Notch2 NRR antibodies. Cells were stained with anti-CD21/35 and anti-CD23 antibodies. Circled areas define $\mathrm{CD} 21 / 35^{\text {high }} \mathrm{CD}_{23}{ }^{-}$MZBs and $\mathrm{CD} 21 / 35^{\text {int }} \mathrm{CD} 23^{+}$follicular $B$ cells gated on $\mathrm{B}_{22} 20^{+} / \mathrm{CD}_{19} \mathrm{IgM}^{+} \mathrm{B}$-cell populations. B: Frequencies of MZBs and follicular B cells (FoBs) in Notch2HCS mutant and wild-type littermates treated with anti-ragweed or anti-Notch2 NRR antibodies. Data are expressed as mean (95\% CI) frequencies of MZBs and FoBs (A); data are expressed as means $(95 \% \mathrm{CI})(\mathbf{B}) . n=4$ biological replicates. ${ }^{*} P<0.05$ Notch2HCS versus control; ${ }^{\dagger} P<0.05$ anti-ragweed antibody-treated versus anti-NRR antibody-wild-type mice; ${ }^{\ddagger} P<0.05$ anti-ragweed antibodytreated versus anti-Notch2 NRR antibody-Notch2HCS mice.

agreement with results reported in mice expressing the Notch2 NICD in CD19-expressing cells. ${ }^{18}$ These results suggest that Notch2 activation alone is insufficient to generate B-cell lymphomas, and that additional contributing factors are necessary for the development of B-cell lymphomas in the mouse. It is also possible that 1-year-old mice, the oldest cohort studied, were not sufficiently old to develop lymphoma, since these tumors appear in aging mice. ${ }^{55}$ It is of interest that somatic mutations found in about $25 \%$ of subjects with splenic MZ lymphomas are confined to exon 34 of NOTCH2 and are located upstream of the PEST domain. ${ }^{29,30}$ These mutants, like in the case of HCS, confer gain-of-NOTCH2 function and are associated with adverse clinical outcomes. Individuals affected by HCS have not been reported to have an increased prevalence of MZ B-cell lymphomas. Although the disease is rare, it is presumed that additional genetic alterations are needed for the development of lymphomas. ${ }^{30}$

The approach to down-regulate Notch signaling has been diverse and includes the use of biochemical inhibitors of Notch activation, antibodies to Notch receptors or their ligands, and the use of small permeable molecules that prevent the formation of a NICD/Rbpjk/mastermind-like protein ternary complex. ${ }^{56} \gamma$-Secretase inhibitors block the cleavage of the Notch receptor induced by presenilins, and thapsigargin precludes the maturation and folding of Notch and its exit from the endoplasmic reticulum. ${ }^{57-59}$ However, these agents are not specific and prevent the indiscriminate activation of all Notch receptors. ${ }^{60}$ The long-term efficacy of synthetic small cell permeable molecules that prevent the assembly of an active Notch transcriptional complex is unknown. ${ }^{61}$

To target specific Notch receptors, antibodies to the NRR of Notch1, -2 , and -3 have been developed. ${ }^{33,62}$ The NRR consists of three LIN-12 Notch repeats and a heterodimerization domain, and contains the initial cleavage sites of Notch, which are required for protein maturation and signal activation. ${ }^{7,32}$ The epitope for the anti-Notch2 NRR bridges the LIN-12 Notch repeats and heterodimerization domain so that the antibody locks the receptor in its quiescent state, preventing Notch2 activation. ${ }^{33,34}$ Although Notch2 neutralization was achieved by the use of anti-Notch2 NRR antibodies without negative consequences, Notch neutralization has been reported to cause vascular tumors and gastrointestinal toxicity. ${ }^{63,64}$ The reason we did not encounter these complications probably was related to the low dose and limited duration of the treatment. The antiNotch2 NRR antibody not only prevented the MZ B-cell phenotype of Notch2HCS mice but also markedly decreased the MZ B-cell population in spleens from wild-type mice. These results confirm the dependency of the MZ B-cell population on Notch2 signal activation, an effect attributed to a rapid egress of MZ B cells after the administration of anti-Notch2 NRR antibodies. ${ }^{14-16,65}$

A recent report documented splenomegaly in an individual affected by HCS, but it is not known whether B cells are altered in spleens from subjects with HCS. ${ }^{19}$ It is of interest that Alagille syndrome associated with JAGl mutations does not present with abnormalities in B-cell populations, whereas Alagille syndrome associated with NOTCH2 haploinsufficiency presents with a marked reduction in $\operatorname{IgM}^{+} \operatorname{IgD}{ }^{+} \mathrm{CD} 27^{+} \mathrm{MZ} \mathrm{B}$ cells, supporting a role of NOTCH2 in B-cell allocation also in humans. ${ }^{17}$ It is important to note that humans have a less well-developed MZ of the spleen than do rodents, and that the organization of the marginal and follicular zones in the human spleen differs from that in the mouse. ${ }^{6}$ 
In conclusion, Notch $2 H C S$ mice harboring a mutation found in subjects with HCS exhibit a marked increase in mature MZ B cells, which can be prevented by the administration of anti-Notch2 NRR antibodies.

\section{Acknowledgments}

We thank Genentech (South San Francisco, CA) for the gift of anti-Notch2 NRR and anti-ragweed antibodies, Ryochiro Kageyama (Kyoto University, Kyoto, Japan) for the gift of Hes5 cDNA, Lauren Schilling and David Bridgewater (UConn Health, Farmington, CT) for technical support, and Mary Yurczak for secretarial assistance.

\section{References}

1. Hardy RR, Hayakawa K: B cell development pathways. Annu Rev Immunol 2001, 19:595-621

2. Loder F, Mutschler B, Ray RJ, Paige CJ, Sideras P, Torres R, Lamers MC, Carsetti R: B cell development in the spleen takes place in discrete steps and is determined by the quality of B cell receptorderived signals. J Exp Med 1999, 190:75-89

3. Pillai S, Cariappa A: The follicular versus marginal zone B lymphocyte cell fate decision. Nat Rev Immunol 2009, 9:767-777

4. Pillai S, Cariappa A, Moran ST: Marginal zone B cells. Annu Rev Immunol 2005, 23:161-196

5. Phan TG, Gardam S, Basten A, Brink R: Altered migration, recruitment, and somatic hypermutation in the early response of marginal zone B cells to T cell-dependent antigen. J Immunol 2005, 174:4567-4578

6. Zouali M, Richard Y: Marginal zone B-cells, a gatekeeper of innate immunity. Front Immunol 2011, 2:63

7. Zanotti S, Canalis E: Notch and the skeleton. Mol Cell Biol 2010, 30: 886-896

8. Kovall RA: More complicated than it looks: assembly of Notch pathway transcription complexes. Oncogene 2008, 27:5099-5109

9. Nam Y, Sliz P, Song L, Aster JC, Blacklow SC: Structural basis for cooperativity in recruitment of MAML coactivators to Notch transcription complexes. Cell 2006, 124:973-983

10. Schroeter EH, Kisslinger JA, Kopan R: Notch-1 signalling requires ligand-induced proteolytic release of intracellular domain. Nature 1998, 393:382-386

11. Wilson JJ, Kovall RA: Crystal structure of the CSL-Notch-mastermind ternary complex bound to DNA. Cell 2006, 124:985-996

12. Radtke F, Wilson A, Stark G, Bauer M, van Meerwijk J, MacDonald HR, Aguet M: Deficient T cell fate specification in mice with an induced inactivation of Notch1. Immunity 1999, 10:547-558

13. Witt CM, Hurez V, Swindle CS, Hamada Y, Klug CA: Activated Notch2 potentiates CD8 lineage maturation and promotes the selective development of B1 B cells. Mol Cell Biol 2003, 23:8637-8650

14. Tanigaki K, Han H, Yamamoto N, Tashiro K, Ikegawa M, Kuroda K, Suzuki A, Nakano T, Honjo T: Notch-RBP-J signaling is involved in cell fate determination of marginal zone B cells. Nat Immunol 2002, 3:443-450

15. Saito T, Chiba S, Ichikawa M, Kunisato A, Asai T, Shimizu K, Yamaguchi T, Yamamoto G, Seo S, Kumano K, NakagamiYamaguchi E, Hamada Y, Aizawa S, Hirai H: Notch2 is preferentially expressed in mature B cells and indispensable for marginal zone B lineage development. Immunity 2003, 18:675-685

16. Witt CM, Won WJ, Hurez V, Klug CA: Notch2 haploinsufficiency results in diminished $\mathrm{B} 1 \mathrm{~B}$ cells and a severe reduction in marginal zone B cells. J Immunol 2003, 171:2783-2788

17. Descatoire M, Weller S, Irtan S, Sarnacki S, Feuillard J, Storck S, Guiochon-Mantel A, Bouligand J, Morali A, Cohen J, Jacquemin E, Iascone M, Bole-Feysot C, Cagnard N, Weill JC, Reynaud CA:
Identification of a human splenic marginal zone B cell precursor with NOTCH2-dependent differentiation properties. J Exp Med 2014, 211: 987-1000

18. Hampel F, Ehrenberg S, Hojer C, Draeseke A, Marschall-Schroter G, Kuhn R, Mack B, Gires O, Vahl CJ, Schmidt-Supprian M, Strobl LJ, Zimber-Strobl U: CD19-independent instruction of murine marginal zone B-cell development by constitutive Notch2 signaling. Blood $2011,118: 6321-6331$

19. Adami G, Rossini M, Gatti D, Orsolini G, Idolazzi L, Viapiana O, Scarpa A, Canalis E: Hajdu Cheney syndrome; report of a novel NOTCH2 mutation and treatment with denosumab. Bone 2016, 92:150-156

20. Canalis E, Zanotti S: Hajdu-Cheney syndrome, a disease associated with NOTCH2 mutations. Curr Osteoporos Rep 2016, 14:126-131

21. Cheney WD: Acro-osteolysis. Am J Roentgenol Radium Ther Nucl Med 1965, 94:595-607

22. Hajdu N, Kauntze R: Cranio-skeletal dysplasia. Br J Radiol 1948, 21 : $42-48$

23. Gray MJ, Kim CA, Bertola DR, Arantes PR, Stewart H, Simpson MA, Irving MD, Robertson SP: Serpentine fibula polycystic kidney syndrome is part of the phenotypic spectrum of Hajdu-Cheney syndrome. Eur J Hum Genet 2012, 20:122-124

24. Isidor B, Lindenbaum $\mathrm{P}$, Pichon $\mathrm{O}$, Bezieau $\mathrm{S}$, Dina $\mathrm{C}$, Jacquemont $\mathrm{S}$, Martin-Coignard D, Thauvin-Robinet C, Le MM, Mandel JL, David A, Faivre L, Cormier-Daire V, Redon R, Le CC: Truncating mutations in the last exon of NOTCH2 cause a rare skeletal disorder with osteoporosis. Nat Genet 2011, 43:306-308

25. Majewski J, Schwartzentruber JA, Caqueret A, Patry L, Marcadier J, Fryns JP, Boycott KM, Ste-Marie LG, McKiernan FE, Marik I Van EH, Michaud JL, Samuels ME: Mutations in NOTCH2 in families with Hajdu-Cheney syndrome. Hum Mutat 2011, 32:1114-1117

26. Simpson MA, Irving MD, Asilmaz E, Gray MJ, Dafou D, Elmslie FV, Mansour S, Holder SE, Brain CE, Burton BK, Kim KH, Pauli RM, Aftimos S, Stewart H, Kim CA, Holder-Espinasse M, Robertson SP, Drake WM, Trembath RC: Mutations in NOTCH2 cause Hajdu-Cheney syndrome, a disorder of severe and progressive bone loss. Nat Genet 2011, 43:303-305

27. Zhao W, Petit E, Gafni RI, Collins MT, Robey PG, Seton M, Miller KK, Mannstadt M: Mutations in NOTCH2 in patients with Hajdu-Cheney syndrome. Osteoporos Int 2013, 24:2275-2281

28. Lee SY, Kumano K, Nakazaki K, Sanada M, Matsumoto A Yamamoto G, Nannya Y, Suzuki R, Ota S, Ota Y, Izutsu K, SakataYanagimoto M, Hangaishi A, Yagita H, Fukayama M, Seto M, Kurokawa M, Ogawa S, Chiba S: Gain-of-function mutations and copy number increases of Notch2 in diffuse large B-cell lymphoma. Cancer Sci 2009, 100:920-926

29. Rossi D, Trifonov V, Fangazio M, Bruscaggin A, Rasi S, Spina V et al: The coding genome of splenic marginal zone lymphoma: acti vation of $\mathrm{NOTCH} 2$ and other pathways regulating marginal zone development. J Exp Med 2012, 209:1537-1551

30. Kiel MJ, Velusamy T, Betz BL, Zhao L, Weigelin HG, Chiang MY, Huebner-Chan DR, Bailey NG, Yang DT, Bhagat G, Miranda RN, Bahler DW, Medeiros LJ, Lim MS, Elenitoba-Johnson KS: Wholegenome sequencing identifies recurrent somatic NOTCH2 mutations in splenic marginal zone lymphoma. J Exp Med 2012, 209:1553-1565

31. Canalis E, Schilling L, Yee SP, Lee SK, Zanotti S: Hajdu Cheney mouse mutants exhibit osteopenia, increased osteoclastogenesis and bone resorption. J Biol Chem 2016, 291:1538-1551

32. Zanotti S, Canalis E: Notch signaling and the skeleton. Endocr Rev 2016, 37:223-253

33. Wu Y, Cain-Hom C, Choy L, Hagenbeek TJ, de Leon GP, Chen Y, Finkle D, Venook R, Wu X, Ridgway J, Schahin-Reed D, Dow GJ, Shelton A, Stawicki S, Watts RJ, Zhang J, Choy R, Howard P, Kadyk L, Yan M, Zha J, Callahan CA, Hymowitz SG, Siebel CW Therapeutic antibody targeting of individual Notch receptors. Nature 2010, 464:1052-1057

34. Aste-Amezaga M, Zhang N, Lineberger JE, Arnold BA, Toner TJ Gu M, Huang L, Vitelli S, Vo KT, Haytko P, Zhao JZ, Baleydier F, 
L'Heureux S, Wang H, Gordon WR, Thoryk E, Andrawes MB, Tiyanont K, Stegmaier K, Roti G, Ross KN, Franlin LL, Wang H, Wang F, Chastain M, Bett AJ, Audoly LP, Aster JC, Blacklow SC, Huber HE: Characterization of Notch1 antibodies that inhibit signaling of both normal and mutated Notch1 receptors. PLoS One 2010, 5:e9094

35. Canalis E, Sanjay A, Yu J, Zanotti S: An antibody to Notch2 reverses the osteopenic phenotype of Hajdu-Cheney mutant male mice. Endocrinology 2017, 158:730-742

36. Mankarious S, Lee M, Fischer S, Pyun KH, Ochs HD, Oxelius VA, Wedgwood RJ: The half-lives of IgG subclasses and specific antibodies in patients with primary immunodeficiency who are receiving intravenously administered immunoglobulin. J Lab Clin Med 1988, 112:634-640

37. Jheon AH, Prochazkova M, Meng B, Wen T, Lim YJ, Naveau A, Espinoza R, Cox TC, Sone ED, Ganss B, Siebel CW, Klein OD: Inhibition of notch signaling during mouse incisor renewal leads to enamel defects. J Bone Miner Res 2016, 31:152-162

38. Huntzicker EG, Hotzel K, Choy L, Che L, Ross J, Pau G, Sharma N, Siebel CW, Chen X, French DM: Differential effects of targeting Notch receptors in a mouse model of liver cancer. Hepatology 2015, 61:942-952

39. Lafkas D, Shelton A, Chiu C, de Leon Boenig G, Chen Y, Stawicki SS, Siltanen C, Reichelt M, Zhou M, Wu X, EasthamAnderson J, Moore H, Roose-Girma M, Chinn Y, Hang JQ, Warming S, Egen J, Lee WP, Austin C, Wu Y, Payandeh J, Lowe JB, Siebel CW: Therapeutic antibodies reveal Notch control of transdifferentiation in the adult lung. Nature 2015, 528:127-131

40. Nazarenko I, Pires R, Lowe B, Obaidy M, Rashtchian A: Effect of primary and secondary structure of oligodeoxyribonucleotides on the fluorescent properties of conjugated dyes. Nucleic Acids Res 2002, 30:2089-2195

41. Nazarenko I, Lowe B, Darfler M, Ikonomi P, Schuster D, Rashtchian A: Multiplex quantitative PCR using self-quenched primers labeled with a single fluorophore. Nucleic Acids Res 2002, 30:e37

42. Akazawa C, Sasai Y, Nakanishi S, Kageyama R: Molecular characterization of a rat negative regulator with a basic helix-loop-helix structure predominantly expressed in the developing nervous system. J Biol Chem 1992, 267:21879-21885

43. Kutyavin IV, Afonina IA, Mills A, Gorn VV, Lukhtanov EA, Belousov ES, Singer MJ, Walburger DK, Lokhov SG, Gall AA, Dempcy R, Reed MW, Meyer RB, Hedgpeth J: 3'-minor groove binder-DNA probes increase sequence specificity at PCR extension temperatures. Nucleic Acids Res 2000, 28:655-661

44. Gibson DG, Young L, Chuang RY, Venter JC, Hutchison CA 3rd, Smith HO: Enzymatic assembly of DNA molecules up to several hundred kilobases. Nat Methods 2009, 6:343-345

45. Miyazaki T, Sanjay A, Neff L, Tanaka S, Horne WC, Baron R: Src kinase activity is essential for osteoclast function. J Biol Chem 2004, 279:17660-17666

46. Zagouras P, Stifani S, Blaumueller CM, Carcangiu ML, ArtavanisTsakonas S: Alterations in Notch signaling in neoplastic lesions of the human cervix. Proc Natl Acad Sci U S A 1995, 92:6414-6418

47. Adapala NS, Barbe MF, Langdon WY, Nakamura MC, Tsygankov AY, Sanjay A: The loss of Cbl-phosphatidylinositol 3-kinase interaction perturbs RANKL-mediated signaling, inhibiting bone resorption and promoting osteoclast survival. J Biol Chem 2010, 285:36745-36758

48. Adapala NS, Barbe MF, Tsygankov AY, Lorenzo JA, Sanjay A: Loss of Cbl-PI3K interaction enhances osteoclast survival due to p21-Ras mediated PI3K activation independent of Cbl-b. J Cell Biochem 2014, 115:1277-1289
49. Hammad H, Vanderkerken M, Pouliot P, Deswarte K, Toussaint W, Vergote K, Vandersarren L, Janssens S, Ramou I, Savvides SN, Haigh JJ, Hendriks R, Kopf M, Craessaerts K, de Strooper B, Kearney JF, Conrad DH, Lambrecht BN: Transitional B cells commit to marginal zone B cell fate by Taok3-mediated surface expression of ADAM10. Nat Immunol 2017, 18:313-320

50. Gibb DR, El Shikh M, Kang DJ, Rowe WJ, El Sayed R, Cichy J, Yagita H, Tew JG, Dempsey PJ, Crawford HC, Conrad DH: ADAM10 is essential for Notch2-dependent marginal zone B cell development and CD23 cleavage in vivo. J Exp Med 2010, 207:623-635

51. Lortan J, Gray D, Kumararatne DS, Platteau B, Bazin H, MacLennan IC: Regulation of the size of the recirculating B cell pool of adult rats. Adv Exp Med Biol 1985, 186:593-601

52. Jin WJ, Kim B, Kim JW, Kim HH, Ha H, Lee ZH: Notch2 signaling promotes osteoclast resorption via activation of PYK2. Cell Signal 2016, 28:357-365

53. Guinamard R, Okigaki M, Schlessinger J, Ravetch JV: Absence of marginal zone B cells in Pyk-2-deficient mice defines their role in the humoral response. Nat Immunol 2000, 1:31-36

54. Clayton E, Bardi G, Bell SE, Chantry D, Downes CP, Gray A, Humphries LA, Rawlings D, Reynolds H, Vigorito E, Turner M: A crucial role for the p110delta subunit of phosphatidylinositol 3-kinase in B cell development and activation. J Exp Med 2002, 196:753-763

55. Ward JM: Lymphomas and leukemias in mice. Exp Toxicol Pathol 2006, 57:377-381

56. Ryeom SW: The cautionary tale of side effects of chronic Notch 1 inhibition. J Clin Invest 2011, 121:508-509

57. De Strooper B, Annaert W, Cupers P, Saftig P, Craessaerts K, Mumm JS, Schroeter EH, Schrijvers V, Wolfe MS, Ray WJ, Goate A, Kopan R: A presenilin-1-dependent gamma-secretase-like protease mediates release of Notch intracellular domain. Nature 1999, 398: $518-522$

58. Ilagan MX, Kopan R: Selective blockade of transport via SERCA inhibition: the answer for oncogenic forms of Notch? Cancer Cell 2013, 23:267-269

59. Largaespada D, Ratner N: Interweaving the strands: beta-catenin, an HIV co-receptor, and Schwann cell tumors. Cancer Cell 2013, 23: 269-271

60. Duggan SP, McCarthy JV: Beyond gamma-secretase activity: the multifunctional nature of presenilins in cell signalling pathways. Cell Signal 2016, 28:1-11

61. Moellering RE, Cornejo M, Davis TN, Del BC, Aster JC, Blacklow SC, Kung AL, Gilliland DG, Verdine GL, Bradner JE: Direct inhibition of the NOTCH transcription factor complex. Nature 2009, 462:182-188

62. Li K, Li Y, Wu W, Gordon WR, Chang DW, Lu M, Scoggin S, Fu T, Vien L, Histen G, Zheng J, Martin-Hollister R, Duensing T, Singh S, Blacklow SC, Yao Z, Aster JC, Zhou BB: Modulation of Notch signaling by antibodies specific for the extracellular negative regulatory region of NOTCH3. J Biol Chem 2008, 283:8046-8054

63. Ridgway J, Zhang G, Wu Y, Stawicki S, Liang WC, Chanthery Y, Kowalski J, Watts RJ, Callahan C, Kasman I, Singh M, Chien M, Tan C, Hongo JA, de Sauvage F, Plowman G, Yan M: Inhibition of D114 signalling inhibits tumour growth by deregulating angiogenesis. Nature 2006, 444:1083-1087

64. Yan M, Callahan CA, Beyer JC, Allamneni KP, Zhang G, Ridgway JB, Niessen K, Plowman GD: Chronic DLL4 blockade induces vascular neoplasms. Nature 2010, 463:E6-E7

65. Simonetti G, Carette A, Silva K, Wang H, De Silva NS, Heise N, Siebel CW, Shlomchik MJ, Klein U: IRF4 controls the positioning of mature B cells in the lymphoid microenvironments by regulating NOTCH2 expression and activity. J Exp Med 2013, 210:2887-2902 